\title{
Co-relationship between Escherichia coli in broiler cellulitis and liver lesions
}

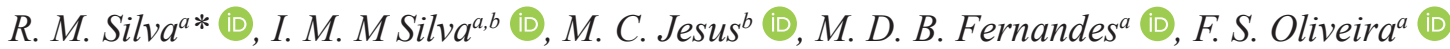 \\ and J. Evêncio-Neto ${ }^{c}$
}

${ }^{a}$ Universidade Federal do Recôncavo da Bahia - UFRB, Complexo Multidisciplinar de Estudo e Pesquisa em Saúde, Santo Antônio de Jesus, BA, Brasil

${ }^{b}$ Centro de Ciências Agrárias Ambientais e Biológicas - UFRB, Programa de Pós-graduação em Microbiologia Agrícola, Cruz das Almas, BA, Brasil

'Universidade Federal Rural de Pernambuco, Departamento de Histopatologia, Recife, PE, Brasil

*e-mail: ricardomendes@ufrb.edu.br

Received: October 22, 2019 - Accepted: March 18, 2020 - Distributed: August 31, 2021

\begin{abstract}
Pathogenic strains of Escherichia coli may invade the subcutaneous tissue of poultry and cause cellulitis, whilst the pathogen may also cause lesions in internal organs such as the liver. Current paper co-relates Escherichia coli and virulence genes characteristic of Avian Pathogenic Escherichia coli (APEC) in broilers' cellulitis and liver lesions. One hundred carcasses were retrieved from the production chain in an avian abattoir in the state of Bahia, Brazil, between August 2013 and January 2014, due to detection of cellulitis lesions. Cellulitis and liver samples were retrieved aseptically to quantify E. coli by Petrifilm ${ }^{\mathrm{TM}}$ count fast method (3M Company) (AOAC 998.8). Virulent genes iss and iutA were removed from E. coli isolates by Polymerase Chain Reaction (PCR). Escherichia coli was isolated from $82.0 \%$ of broilers removed from the production chain and the bacterium was concomitantly detected in cellulitis and liver lesions in $40.0 \%$ of broilers. $E$. coli counts ranged between 1.00 and $4.73 \mathrm{log}$ CFU/g in liver lesions and between 2.00 and $9.00 \mathrm{log} \mathrm{UFC} / \mathrm{g}$ in cellulitis lesions. Virulent genes iutA and iss were detected in $97.56 \%$ and $89.02 \%$ of E. coli isolates, respectively. Genotype analysis demonstrated the concomitant amplification of genes iutA and iss in $60.0 \%$ $(n=40)$ of samples of cellulitis and liver lesions in which the simultaneous isolation of $E$. coli occurred. There was a positive and significant co-relationship $(\mathrm{r}=0.22 ; \mathrm{p}<0.05)$ between the variables occurrence of $E$. coli isolated from liver samples and the occurrence of E. coli isolated from cellulitis lesions. There were also positive and significant co-relationships between populations of $E$. coli from liver isolates and cellulitis lesions $(\mathrm{r}=0.46 ; \mathrm{p}<0.05)$ when $E$. coli isolated in the liver and in cellulitis lesions was detected. Since results showed a relationship between $E$. coli in cellulitis and liver lesions and possible systemic infection, the occurrence of cellulitis lesions as a criterion for total discarding of carcass may be suggested.
\end{abstract}

Keywords: sanitary inspection, enterobacteriaceae, microbial genetics, food and nutritional safety.

\section{Correlação entre a presença de Escherichia coli em lesões de celulite e fígados de frango}

\section{Resumo}

Cepas patogênicas de Escherichia coli podem invadir o tecido subcutâneo das aves e provocar celulite aviária e este patógeno pode provocar lesões nos órgãos internos, como o fígado. Desta forma, objetivou-se correlacionar a presença de Escherichia coli e os genes de virulência característicos de Escherichia coli Patogênica para Aves (APEC) nas lesões de celulite e nos fígados dos frangos. Entre agosto de 2013 a janeiro de 2014, foram retiradas 100 carcaças da linha de produção por apresentarem lesões de celulite em um matadouro avícola da Bahia (Brasil). Foram coletadas amostras de celulite e fígados de frango assepticamente para quantificação de $E$. coli pelo método rápido de contagem Petrifilm ${ }^{\mathrm{TM}}$ (3M Company) (AOAC 998.8). Em seguida foi realizada a pesquisa dos genes de virulência iss e iutA nos isolados de E. coli utilizando a Reação em Cadeia da Polimerase (PCR). Escherichia coli foi isolada em $82,00 \%$ das aves retiradas da linha de produção e a bactéria foi detectada concomitantemente nas lesões de celulite e fígado em $40,00 \%$ das aves. As contagens de $E$. coli variaram de 1,00 a 4,73 log UFC/g nos fígados e de 2,00 a 9,00 log UFC/g nas lesões de celulite. Os genes de virulência iutA e iss foram encontrados em 97,56\% e 89,02\% dos isolados de $E$. coli, respectivamente. A análise genotípica revelou a amplificação concomitante dos genes iutA e iss em $60,00 \%(\mathrm{n}=40)$ das amostras de lesões de celulite e fígado nas quais houve o isolamento simultâneo de $E$. coli. Foi observada correlação positiva e significativa $(\mathrm{r}=0,22 ; \mathrm{p}<0,05)$ entre as variáveis ocorrência de $E$. coli isolada das amostras dos fígados e 
ocorrência $E$. coli isolada das lesões de celulite e, nos casos em que foi detectada a ocorrência de $E$. coli isolada em fígado e lesões de celulite, correlações positivas e significativas também foram evidenciadas entre as populações de E. coli dos isolados dos fígados e das lesões de celulite, $(\mathrm{r}=0,46 ; \mathrm{p}<0,05)$. Assim ficou evidenciada a relação entre E. coli presente nas lesões de celulite e no fígado e uma possível infecção sistêmica, desta forma, sugere-se que a presença de lesões de celulite seja utilizada como critério para o descarte total da carcaça.

Palavras-chave: inspeção sanitária, enterobacteriaceae, genética microbiana, segurança alimentar e nutricional.

\section{Introduction}

The avian industry has a robust economic impact since it produces low-cost animal protein. In 2017, Brazil produced 13,056,000 tons of broiler meat, ranking second worldwide. Further, Brazil exported 4,320,000 tons of broiler meat and derived products, ranking first in export worldwide (ABPA, 2018). However, Brazil has to increase its production efficiency, meet meat quality criteria and other requirements related to animal well fare and the environment so that such ranking may be maintained (Paschoal et al., 2012).

In spite of good performance, poultry culture has serious avian health issues to due to the industrial scale in broiler breeding. In fact, cutaneous diseases, particularly avian cellulitis, have become more and more frequent and have produced liabilities to poultry production, caused by the partial or total discard of carcasses in abattoirs (Vieira et al., 2014).

The main characteristics of broiler cellulitis are subcutaneous inflammation, especially on thighs and abdomen, and microscopic changes, such as skin thickening and irregularities with color alterations and with the formation of yellow plates detected under the skin (Ghanbarpour et al., 2010). Poultry cellulitis is mainly caused by inadequate management and nutrition and through pathogens, such as Escherichia coli, which invade the organism from a continuous solution in the skin (Vieira et al. 2006). Research on virulence genes in $E$. coli isolates identifies pathogenic strains in samples of several types of food (Barbosa et al., 2019; Silva et al., 2012) and is an important strategy to diagnose pathogenic strains.

Studies by Gomis et al. (2000) have shown that cellulitis-struck broilers may have also lesions in the heart, aerial pathways, bones, joints and liver. Within the internal organs, the liver may provide relevant information on the occurrence of systemic illnesses even though the etiology of several hepatic lesions cannot be pinpointed (AbdulAziz et al., 2016; Swayne, 2013).

Underscoring public health, the Ministry of Agriculture, Livestock and Supply insists that any organ or any segment in broiler carcass affected by an inflammation process should be discarded and, if there is evidence of systemic issues, the carcass and the viscera should be totally rejected (Brasil, 1998).

Due to the lack of studies that co-relate microbiological and molecular findings in broilers' cellulitis and liver lesions, current analysis co-relates $E$. coli and virulence genes characteristics of Avian Pathogenic Escherichia coli (APEC) in broilers' cellulitis and liver lesions.

\section{Material and Methods}

One hundred samples of cellulitis and liver lesions of broilers (Gallus gallus), with cellulitis lesions were collected in a poultry abattoir in the Reconcavo Sul of the state of Bahia (Brazil), monitored by the Agriculture and Livestock Agency of Bahia (ADAB), between August 2013 and January 2014.

Samples were collected aseptically with a scalpel lamina and placed in sterile containers. They were identified and transported in an isothermal icebox and immediately sent to the Center for Health Studies and Research at the Center of Health Sciences of the Universidade Federal do Recôncavo da Bahia.

Escherichia coli was isolated by fast count method in Petrifilm ${ }^{\mathrm{TM}}$ plates (3M Company), with Petrifilm EC ${ }^{\mathrm{TM}}$ Plate (AOAC 998.8), following instructions by manufacturer. Colony counts were undertaken by colony counter CP600 Plus (Phoenix ${ }^{\circledR}$ ) which calculated the number of $\log \mathrm{CFU} / \mathrm{g}$ (Silva et al., 2017).

At first, up to three colonies typical of E. coli were isolated, originating from Petrifilm ECTM plates (3M Company). Each colony was inoculated with a platinum handle or needle in a microtube with Brain Heart Infusion (BHI) broth, at $35 \pm 1^{\circ} \mathrm{C}$ for $24 \pm 2 \mathrm{~h}$. After this period, $2 \mathrm{~mL}$ glycerol $15 \%$ were added and samples were frozen at minus $20^{\circ} \mathrm{C}$ for DNA extraction later on.

For DNA extraction, samples were inoculated in BHI broth and incubated at $35 \pm 1^{\circ} \mathrm{C}$ for $24 \pm 2 \mathrm{~h}$. They were then centrifuged for $5 \mathrm{~min}$, at 13,500 rpm. Supernatant was discarded and $800 \mu \mathrm{L}$ of ionized water were added. Homogenization and centrifuge were undertaken in the same conditions as described above. Supernatant was once again discarded, $80 \mu \mathrm{L}$ of deionized water were added and the resulting content homogenized. Samples were then heated at $96^{\circ} \mathrm{C}$ for $10 \mathrm{~min} ; 2 \mu \mathrm{L}$ of supernatant was placed in a microtube with $18 \mu \mathrm{L}$ of ultrapure water (Hexapur $\left.{ }^{\mathrm{TM}}\right)$. DNA samples were stored at minus $20^{\circ} \mathrm{C}$ until analysis.

DNA was quantified by spectrophotometry (BioPhotometer D30 Eppendorf( $(\mathrm{TM})$ and standardized with final concentration of $50 \mathrm{ng} / 10 \mu \mathrm{L}$. Virulence genes prevalent in pathotypes APEC (iss and iutA) were analyzed by Polymerase Chain Reaction (PCR).

Table 1 described the characteristics of primers.

The mix was prepared in an aseptic chamber and $24 \mu \mathrm{L}$ were distributed in $0.2 \mathrm{~mL}$ polypropylene tubes, while 
$1 \mu \mathrm{L}$ of each DNA sample was added per tube. Ultrapure water (Hexapur ${ }^{\mathrm{TM}}$ ) was employed for negative control; standard strains APEC (ATCC 25922), provided by the Oswaldo Cruz Foundation of Rio de Janeiro, were used as positive control. PCR was undertaken in Mastercycler (Amplitherm ${ }^{\mathrm{TM}}$ ) thermocycler.

Further, $10 \mu \mathrm{L}$ of the amplified product, positive and negative controls, and $2 \mu \mathrm{L}$ of molecular weight of $100 \mathrm{pb}$ DNA ladder were added to each well of agar gel $2 \%$, stained with ethidium bromide $(10 \mathrm{mg} / \mathrm{mL})$. Separation was done by electrophoresis with GSR $\AA 1000$ STD at the following conditions: 100 minutes, $60 \mathrm{~V}, 37 \mathrm{~mA}$ and $2 \mathrm{~W}$. Results were reported on ultraviolet trans-illuminator (Loccus ${ }^{\circledR}$ ).

Statistical analysis was performed with SPSS 22.0, featuring means and standard deviation in the descriptive analysis of data and percentage frequencies for qualitative variables. Pearson's Correlation Test was employed to compare frequencies of occurrence in the isolation of Escherichia coli of cellulitis and liver lesions and of the quantification of Escherichia coli isolates in cellulitis and liver lesions at 0.05 significance level.

\section{Results and Discussion}

Escherichia coli was isolated in $82.0 \%$ of cellulitis samples and in $45.0 \%$ of liver samples. Bacterium was detected concomitantly in cellulitis and liver lesions in $40.0 \%$ of broilers (Table 2).

Escherichia coli counts in liver isolates ranged between 1.00 and $4.73 \log \mathrm{CFU} / \mathrm{g}$ and in cellulitis lesions between 2.00 and $9.00 \log \mathrm{CFU} / \mathrm{g}$, corroborating results by Vieira et al. (2013) who isolated Escherichia coli strains in 50 broiler samples from an abattoir in the state of Rio de Janeiro, where the bacterium occurred simultaneously in $50.0 \%(n=25)$ of cellulitis and liver lesions.
Contrasting results were provided by Gomis et al. (2001) in a Canadian research. The authors isolated Escherichia coli in 237 cellulitis samples. The bacterium was also isolated in only three samples of the above lesions in the liver with macroscopic lesions. However, the lack of macroscopic finds failed to guarantee the organ's harmlessness. In fact, Silva et al. (2012) isolated Escherichia coli in $60 \%(\mathrm{n}=30)$ of samples of broilers' livers without any macroscopic alterations, in the Recôncavo da Bahia region.

There was a positive and significant co-relationship $(\mathrm{r}=0.22 ; \mathrm{p}<0.05)$ between variable occurrence of Escherichia coli isolated from liver samples and Escherichia coli isolated from cellulitis lesions, by Pearson's linear correlation coefficient.

Brito et al. (2003) stated that Escherichia coli strains, isolated from cellulitis, were more associated with the emergence of sepsis than isolates of other clinical manifestations of colibacillosis. Johnson et al. (2001) experimentally inoculated Escherichia coli in broilers to favor the emergence of cellulitis lesions and detected other clinical manifestations of colibacillosis in most contaminated broilers, particularly perihepatitis, pericarditis and aerosaculitis.

Another positive and significant co-relationship for samples in which $E$. coli was isolated in the liver and in cellulitis lesions occurred between $E$. coli counts of livers and cellulitis lesions $(\mathrm{r}=0.46 ; \mathrm{p}<0.05)$. Consequently, the greater the occurrence of cellulitis lesions, the greater is the bacterial population in the livers, corroborating results by Vieira et al. (2013). The authors suggest that Escherichia coli strains penetrate the animal organism through the cellulitis lesion and reach the internal organs.

Virulence genes iutA and iss occurred in $97.56 \%$ and $89.02 \%$ of $E$. coli isolates, respectively. Genotype analysis revealed the concomitant amplification of genes iut $\mathrm{A}$ and iss, characteristic of APEC, in $60.0 \%(\mathrm{n}=40)$ of samples of cellulitis and liver lesions in which the simultaneous

Table 1. Characteristics of PCR primers in samples of cellulitis and liver lesions of broilers from the avian abattoir of the Recôncavo da Bahia (Brazil). 2014

\begin{tabular}{cccc}
\hline Gene & Sequence of oligonucleotides & Amplicom (MW) & Function \\
\hline iss $^{*}$ & $\begin{array}{c}\text { GTGGCGAAAACTAGTAAAACAGC } \\
\text { CGCCTCGGGGTGGATAA }\end{array}$ & 760 & Resistance to serum \\
iutA $^{* *}$ & $\begin{array}{c}\text { GGCTGGACATCATGGGAACTGG } \\
\text { CGTCGGGAACGGGTAGAATCG }\end{array}$ & 302 & Iron acquisition \\
\hline
\end{tabular}

*Source: Knöbl et al. (2012); **Source: Johnson et al. (2008). MW- Molecular Weight.

Table 2. Frequency of Escherichia coli and virulence genes in samples of cellulitis and liver lesions of broilers from avian abattoir of the Recôncavo da Bahia (Brazil). 2014

\begin{tabular}{lccc}
\hline Find /Site & Cellulites & Livers & Cellulites and Livers \\
\hline Escherichia coli & $82 / 100^{*}$ & $45 / 100^{*}$ & $40 / 100^{*}$ \\
iutA & $80 / 82$ & $43 / 45$ & $38 / 40$ \\
Iss & $73 / 82$ & $29 / 45$ & $24 / 40$ \\
iut A and iss & $24 / 40$ & $24 / 40$ & $24 / 40$ \\
\hline
\end{tabular}

*100 number of carcasses with cellulitis lesions retrieved from broilers in the production chain of avian abattoir in the Recôncavo da Bahia. 
isolation of $E$. coli occurred. Azam et al. (2019) researched broilers with colibacillosis in Pakistan and detected that the genes were the most prevalent in APEC, with 74.6\% and $84.0 \%$, respectively.

Brito et al. (2003) identified Escherichia coli strains originating from cellulitis lesions, with similar virulence factors in 52 batches of broilers from the southern states of Brazil. The authors suggested the pathogen's endemic dissemination.

According to Rodriguez-Siek et al. (2005), chicken meat is a possible vector for APEC dissemination, or rather, an extra-intestine $E$. coli (ExPEC) with zoonotic potential. According to Maluta et al. (2014), APEC shares homology of genomic sequences between strains of other human ExPECs (NMEC and UPEC), which are important causes of infections in humans.

In the wake of imminent risk by APECs to human health and in collaboration with Vieira et al. (2014) who stated that the partial removal of cellulitis lesions merely lessens the carcass's repugnant aspect, more aesthetic than hygienic, failing to contribute towards the elimination of contamination, one perceives that the official criteria for discarding carcasses should be revised. Current authors suggest that cellulitis lesions should be the criterion for the carcass's total and not merely partial discard. This is due to the possibility of food unsafeness caused by the intake of chicken meat and derived products.

Positive and significant co-relationship between E. coli isolation in cellulitis and liver lesions from broilers bred and slaughtered in the Reconcavo da Bahia region suggests that broilers' cellulitis should be the initiating factor of the pathogenic infectious process which may attack other organs, especially the liver.

Concomitant amplification of the virulence factors iut $\mathrm{A}$ and iss in most cases in which Escherichia coli was simultaneously isolated in cellulitis and liver reinforces the possibility that pathotype APEC would occur in the two tissues. This fact strengthens the hypothesis that the bacterium infects the animal through skin lesions and then attacks the liver. The above boils down to a systemic and not a local factor with regard to results on cellulitis lesions.

The relationship between $E$. coli in cellulitis and liver lesions and a possible systemic infection is evidenced. It may be suggested that the occurrence of cellulitis lesions may be employed as a criterion for the total discarding of the carcass. The health of the consumer and the elimination of risks within the broilers' production chain are ensured.

\section{Acknowledgements}

Thanks are due to the Coordination of Upgrading in Higher Education for the scholarships awarded, and to the Oswaldo Cruz Foundation (Fiocruz) of Rio de Janeiro for providing standard strains used as positive controls.

\section{References}

ABDUL-AZIZ, T., FLETCHER, O.J. and BARNES, H.J., 2016. Avian histopathology. 4th ed. Florida: American Association of Avian Pathologists.
ASSOCIAÇÃO BRASILEIRA DE PROTEÍNA ANIMAL ABPA, 2018 [viewed 7 October 2019]. Relatório Anual 2018 [online]. Avaiable from: http://abpa-br.com.br/storage/files/ relatorio-anual-2018.pdf

AZAM, M., MOHSIN, M., SAJJAD-UR-RAHMAN. and SALEEMI, M.K., 2019. Virulence-associated genes and antimicrobial resistance among avian pathogenic Escherichia coli from colibacillosis affected broilers in Pakistan. Tropical Animal Health and Production, vol. 51, no. 5, pp. 1259-1265. http://dx.doi.org/10.1007/s11250-01901823-3. PMid:30701453.

BARBOSA, C.A., CONCEIÇÃO, T.A., BALIZA, M.D., CAMILO, V.M.A., JUIZ, P.J.L. and SILVA, I.M.M., 2019. Virulence genes in Escherichia coli isolates from commercialized saltwater mussels Mytella guyanensis (Lamarck, 1819). Brazilian Journal of Biology = Revista Brasileira de Biologia, vol. 79, no. 4, pp. 625-628. http://dx.doi.org/10.1590/1519-6984.185930. PMid:30379238.

BRASIL. Ministério da Agricultura, Pecuária e Abastecimento - MAPA, 1998. [viewed 7 October 2019]. Portaria n 210, de 10 de novembro de 1998. Regulamento Técnico da Inspeção Tecnológica e Higiênico-Sanitária de Carne de Aves. Diário Oficial da República Federativa do Brasil, Brasília, 10 nov. Avaiable from: http://extranet.agricultura.gov.br/sislegis-consulta/ consultarLegislacao.do?operacao $=$ visualizar\&id $=1129$

BRITO, B.G., GAZIRI, L.C. and VIDOTTO, M.C., 2003. Virulence factors and clonal relationships among Escherichia coli strains isolated from broiler chickens with cellulitis. Infection and Immunity, vol. 71, no. 7, pp. 4175-4177. http://dx.doi.org/10.1128/ IAI.71.7.4175-4177.2003. PMid:12819112.

GHANBARPOUR, R., SALEHI, M. and OSWALD, E., 2010. Virulence genotyping of Escherichia coli isolates from avian cellulitis in relation to phylogeny. Comparative Clinical Pathology, Londres, vol. 19, no. 2, pp. 147-153. http://dx.doi.org/10.1007/ s00580-009-0837-4.

GOMIS, S.M., GOMIS, A.I.U., HORADAGODA, N.U., WIJEWARDENE, T.G., ALLAN, B.J. and POTTER, A.A., 2000. Studies on Cellulitis and Other Disease Syndromes Caused by Escherichia coli in Broilers in Sri Lanka. Tropical Animal Health and Production, vol. 32, no. 6, pp. 341-351. http://dx.doi. org/10.1023/A:1005293400605. PMid:11147273.

GOMIS, S.M., RIDDELL, C., POTTER, A.A. and ALLAN, B.J., 2001. Phenotypic and genotypic characterization of virulence factors of Escherichia coli isolated from broiler chickens with simultaneous occurrence of cellulitis and other colibacillosis lesions. Canadian Journal of Veterinary Research, vol. 65, no. 1, pp. 1-6. PMid:11227188.

JOHNSON, L.C., BILGILI, S.F., HOERR, F.J., MCMURTREY, B.L. and NORTON, R.A., 2001. The influence of Escherichia coli strains from different sources and the age of broiler chickens on the development of cellulitis. Avian Pathology, vol. 30, no. 5, pp. 475-478. http://dx.doi.org/10.1080/03079450120078662. PMid:19184936.

JOHNSON, T.J., WANNEMUEHLER, Y.M. and NOLAN, L.K., 2008. Evolution of the iss gene in Escherichia coli. Applied and Environmental Microbiology, vol. 74, no. 8, pp. 2360-2369. http:// dx.doi.org/10.1128/AEM.02634-07. PMid:18281426.

KNÖBL, T., MORENO, A.M., PAIXÃO, R., GOMES, T.A.T., APARECIDA, M., VIEIRA, M., LEITE, D.S., BLANCO, J.E. and FERREIRA, A.J.P., 2012. Prevalence of avian pathogenic Escherichia coli (APEC) clone harboring sfa gene in Brazil. 
TheScientificWorldJournal, vol. 7, pp. 1-8. http://dx.doi. org/10.1100/2012/437342. PMid:22666122.

MALUTA, R.P., LOGUE, C.M., CASAS, M.R., MENG, T., GUASTALLI, E.A., ROJAS, T.C., MONTELLI, A.C., SADATSUNE, T., RAMOS, M. C., NOLAN, L.K. and SILVEIRA, W.D., 2014. Overlapped Sequence Types (STs) and Serogroups of Avian Pathogenic (APEC) and Human Extra-Intestinal Pathogenic (ExPEC) Escherichia coli Isolated in Brazil. PLoS One, vol. 9, no. 8, pp. e105016. http://dx.doi.org/10.1371/journal.pone.0105016. PMid:25115913.

PASCHOAL, E.C., OTUTUMI, L.K. and SILVEIRA, A.P., 2012. Principais causas de condenações no abate de frangos de corte de um abatedouro localizado na região noroeste do Paraná Brasil. Arquivos de Ciências Veterinárias e Zoologia da UNIPAR, vol. 15 , no. 2, pp. 93-97.

RODRIGUEZ-SIEK, K.E., GIDDINGS, C.W., DOETKOTT, C., JOHNSON, T.J. and NOLAN, L.K., 2005. Characterizing the APEC pathotype. Veterinary Research, vol. 36, no. 2, pp. 241256. http://dx.doi.org/10.1051/vetres:2004057. PMid:15720976.

SILVA, I.M.M., BALIZA, M., SANTOS, M.P., REBOUÇAS, L.T., ROCHA, E.V.S., SANTOS, V.A., SILVA, R.M. and EVÊNCIONETO, J., 2012. Presença de Escherichia coli em fígados de frangos provenientes de matadouros avícolas. Revista Brasileira de Saúde e Produção Animal, vol. 13, no. 3, pp. 694-700. http:// dx.doi.org/10.1590/S1519-99402012000300009.
SILVA, N., JUNQUEIRA, V.C.A., SILVEIRA, N.F.A., HIROMI TANIWAKI, M., GOMES, R.A.R. and OKAZAKI, M.M., 2017. Manual de métodos de análise microbiológica de alimentos. 5th ed. São Paulo: Livraria Varela.

SWAYNE, D.E., ed., 2013. Diseases of poultry. 13th ed. Georgia: Wiley Blackwell. http://dx.doi.org/10.1002/9781119421481.

VIEIRA, T.B., FRANCO, R.M., MAGALHÃES, H., PRAXEDES, C.I.S. and TORTELLY, R., 2006. Celulite em frangos de corte abatidos sob inspeção sanitária: aspectos anatomopatológicos associados ao isolamento de Escherichia coli. Revista Brasileira de Ciência Veterinária, vol. 13, no. 3, pp. 174-177. http://dx.doi. org/10.4322/rbcv.2014.388.

VIEIRA, T.B., PEREIRA, V.L.A., FRANCO, R.M., DO NASCIMENTO, E.R., SILVA, R.C.F. and TORTELLY, R., 2014. Potencial patogênico e caráter séptico de Escherichia coli pela identificação dos fatores de virulência iss e felA em celulite e miúdos de frangos sob Inspeção Sanitária. Revista Brasileira de Medicina Veterinária, vol. 36, no. 2, pp. 144-152.

VIEIRA, T.B., PEREIRA, V.L.A., FRANCO, R.M., NASCIMENTO, E.R., LOPES, M.Q.P., GOMES, H.M., ARAÚJO, M.E.I., SUFFYS, P.N. and TORTELLY, R., 2013. Análise molecular de Escherichia coli isoladas de celulite e miúdos (fígado e coração) de frangos sob inspeção sanitária. Revista Brasileira de Medicina Veterinária, vol. 35 , no. 3 , pp. 247-252. 